\title{
SPEECH ACTS ANALYSIS ON PRESIDENT JOKO WIDODO'S CINEMATIC REFERENCE SPEECHES TEXTS
}

\author{
Vebriary Eka Rahmawatia,", Sulistyaningsih ${ }^{\mathrm{b}}$ \\ ${ }^{\mathrm{a}, \mathrm{b}}$ STKIP PGRI Sidoarjo \\ *Corresponding author. E-mail address: vebriaryeka@gmail.com
}

\begin{abstract}
This research aims to describe the types of speech acts that Jokowi delivered in his selected speeches, Jokowi's reasons for committing illocutionary acts seen from the context of the situation behind the speeches, and the prospective perlocutionary effects of the dominant illocutionary acts found in Jokowi's speeches. This is a descriptive qualitative research. The subjects of this research are President Jokowi's speeches texts which contain cinematic references at the World Economic Forum on ASEAN in Hanoi, Vietnam, September 12, 2018 and at the plenary session of the International Monetary Fund (IMF) and World Bank Annual Meetings in Nusa Dua Bali, Indonesia, October 12, 2018. The research findings show that the locutionary acts found in Jokowi's speeches texts is declarative as it has a total percentage $86 \%$ while $11 \%$ is interrogative and $3 \%$ is imperative. Illocutionary acts consist of $55 \%$ of assertive which is followed by directive, expressive, and commissive which occurred respectively $26 \%, 17 \%$, and $2 \%$. Perlocutionary acts consist of $27 \%$ of Hearer is doing something which is followed by Hearer is impressed (24\%), convinced (17\%), attracted $(11 \%)$, feels irritated (7\%), feels frightened (6\%) and inspired (3\%). The reasons of presenting illocutionary acts include giving background information why change has to be made since he realized that the world has change and showing his optimism of economic equality among nations through the fourth industrial revolution. The prospective perlocutionary effects include providing the inspiration for other countries to boost policies related to human resource development program and technology-based creative economy and promoting collaboration and partnership among nations.
\end{abstract}

Keywords: Speech Acts, Cinematic Reference, Locutionary Acts, Illocutionary Acts, Perlocutionary Acts.

\section{INTRODUCTION}

"Language exerts hidden power, like the moon on the tides" is the wise word said by a great novelist, Rita Mae Brown (n.d.). People use language to express ideas and feelings using signals, sounds, and gestures, and for a variety of purposes and reasons. It can also be used as a means of changing reality if it is performed by a powerful figure such as a president. The president utilizes the language as a political instrument to influence society in general. Political speech can be seen as a means of creating and maintaining social relationships, expressing feelings, and selling ideas, policies and programs. Hence, presidential speech is interesting to analyze because of the massive impact on society.

Ones of many interesting presidential speeches are the seventh Indonesian president's speeches, Joko Widodo (known as Jokowi) at the two international economic forums which contain cinematic references. First, on the World Economic Forum on ASEAN in Hanoi, 
Vietnam, September 12, 2018, President Jokowi twisted to the language of famous comic books which became a blockbuster movie to illustrate the threats the world faces today. He took the analogy of the "Avengers: Infinity War" movie where a figure named Thanos threatens to swab out half the earth's population. President Jokowi said he and his fellow Avengers were ready to avoid this from happening by collaboration. The speech became globally viral because of the popular superhero reference. It turned into world trending topic at social media and also as a headline in many online news, TV news, and worldwide newspapers (Septiari, 2018). Second, at the plenary session of the International Monetary Fund (IMF) and the World Bank Annual Meeting in Nusa Dua Bali, Indonesia, October 12, 2018, President Jokowi dropped another cinematic reference by making a comparison of the current global economic situation with "Game of Thrones", HBO's Emmy-winning television series adapted from a series of novels written by George R.R. Martin. His speech even earned standing applause from all the audiences (Gorbiano, 2018).

Speech according to Arsajad (2019) is an activity to express a description or opinion done by someone verbally about something or a problem by expressing a description of the problem using sentences that must be clear in front of the masses or many people at a certain time. The speech must be recognized by the listener so that the speaker's message can be conveyed effectively. Therefore, it is important to recognize the context of the conversation. When the language speakers produce speech in a certain context, they also perform actions like informing, ordering, or requesting. This action is known as speech act.

Speech act is one phenomenon of pragmatics. The words speech acts are derived from two words: speech and act. Speech is the utterance that occurs and act means action. There are three types of speech act according to Austin (1962) and Searle in Rahardi (2005): (1) Locutionary act, (2) Illocutionary act, and (3) Perlocutionary act. Locutionary act is the literal meaning of the utterance. Illocutionary act refers to the extra meaning of the utterance that results from the origin of its literal meaning. Meanwhile, perlocutionary act is related to the influence of the utterance on listener, depending on certain condition. Specifically, Searle in Rahardi (2005) classifies the illocutionary speech acts into five forms as follows: (1) Directive, (2) Commissive, (3) Representative, (4) Declarative, and (5) Expressive. Closely associated with the idea of illocutionary acts is the concept of illocutionary force, the communicative plan, or design behind a speaker's remark (Leech, 1983) which consist of accusing, apologizing, blaming, congratulating, promising, ordering, refusing, swearing, and thanking.

According to Austin in Finch (2000), felicity condition is a proper circumstance which is badly needed in performing speech acts in order to be recognized as intended. Cruse (2006) states that the central topics of linguistic pragmatics are those aspects of meaning which are dependent on context. Meanwhile, Holmes (2015) states that in any situation linguistic choices will generally reflect the influence of one or more of the following components: The participants: (1) who is speaking and (2) who are they speaking to?; The setting or social context of the interaction: where are they speaking?; The topics: what is being talked about?; The function: why are they speaking? Holmes' theory of context is used in this research because Holmes' theory of context is simpler and the theory consists of four components which are enough to analyze a speech act. In addition, political discourse is not only about stating public scheme. It is about politics. It is about doing things with words. Studies on presidential speeches as an aspect of political discourse have been from extensive range of perspectives. This research links the extensive range of political discourse perspectives with the language study which is speech acts analysis. The theoretical 
framework is displayed below in order to ease both the researcher and the reader in understanding the research.

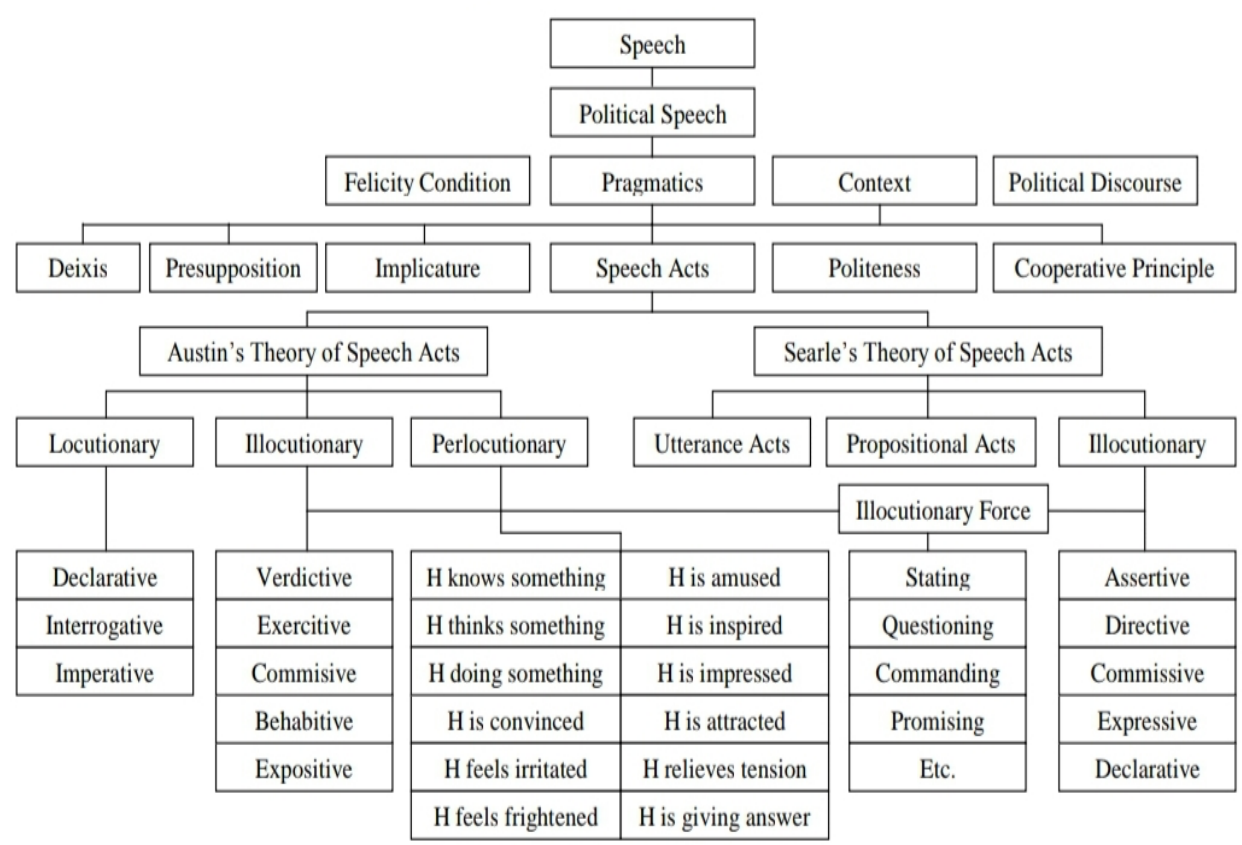

Figure 1. Theoretical Framework

Based on the details above, the objectives of the research are: First, to describe the type of speech acts found in Jokowi's selected speeches in reference to the Austin and Searle classification of speech acts. Second, to describe the reasons why Jokowi performs the kind of illocutionary acts by intensely analyzing words, phrases and sentences considering the context of situations. Third, to describe the prospective perlocutionary effects of the dominant illocutionary found in Jokowi's speeches.

\section{METHOD}

The research is categorized as descriptive qualitative since the data collection is in the form of words rather than numbers. The subjects of this research are President Jokowi's speeches texts which contain cinematic references at the World Economic Forum on ASEAN in Hanoi, Vietnam, September 12, 2018 and at the plenary session of the International Monetary Fund (IMF) and World Bank Annual Meetings in Nusa Dua Bali, Indonesia, October 12, 2018. The speech at the World Economic Forum was presented in English, whether the speech at the IMF and World Bank Annual Meetings was presented in Bahasa Indonesia. However, there was an official translator who directly translated it into English to the hearers or audiences (political, business, academic, and state leaders). The text transcriptions of those two selected speeches' videos were made in order to facilitate the researcher in analyzing the data. Austin's and Searle's theory of speech acts were used to analyze the types of speech acts found in Jokowi's speeches texts. In depth analysis came after by analyzing the reasons of performing such illocutionary acts viewed from its context and the prospective perlocutionary effects of the dominant types of illocutionary acts in Jokowi's speeches texts.

The primary sources of this research are the videos of President Jokowi' speeches at the World Economic Forum on ASEAN in Hanoi, Vietnam, September 12, 2018 and at the plenary session of the International Monetary Fund (IMF) and World Bank Annual Meetings 
in Nusa Dua Bali, Indonesia, October 12, 2018. Both Jokowi's speeches' videos were taken from the website www.youtube.com in order to identify the intonations and gestures. Specifically, the video of Jokowi's speech at the World Economic Forum was downloaded from The Ministry of State of the Republic of Indonesia's official YouTube channel ${ }^{1}$ and the other video was downloaded from World Bank's official YouTube channel ${ }^{2}$. The data are the speeches transcripts which were used to ease the analysis of this research. The text transcriptions were made carefully right after the videos were downloaded. In addition, some articles from the trustworthy newspapers and journals were used as data in order to do in depth analysis about the context, felicity condition, and the political issues at that time. Those data were needed to answer the second and the third statements of the problem in this research.

The main instrument in this research is the researcher herself. In this case, the data were transcribed and read with awareness. Then, the data were analyzed based on Austin's and Searle's theory of the types of speech acts found in Jokowi's speeches, the reasons of performing such illocutionary acts, and the possible perlocutionary effects of the dominant type of illocutionary acts. The second instrument is the data sheets which were utilized as supporting instrument to accomplish the research. The format of the data sheet is illustrated below.

Table 1. The Data Sheet of the Types of Speech Acts Found in Jokowi's Speeches Texts

\begin{tabular}{|c|c|c|c|c|c|c|c|c|c|c|c|}
\hline \multirow{3}{*}{ Code } & \multirow{3}{*}{$\begin{array}{l}\text { Speech } \\
\text { Excerpts }\end{array}$} & \multirow{3}{*}{$\begin{array}{l}\text { Illocutionary } \\
\text { Force }\end{array}$} & \multicolumn{9}{|c|}{ Speech Acts } \\
\hline & & & \multicolumn{3}{|c|}{ Locutionary } & \multicolumn{5}{|c|}{ Illocutionary } & \multirow{2}{*}{$\begin{array}{c}\text { Prospective } \\
\text { Perlocutionary }\end{array}$} \\
\hline & & & $\mathrm{D}$ & In & $\mathrm{Im}$ & Asr & Dir & Com & Exp & Dec & \\
\hline $\mathrm{T} 1 / \mathrm{P} 1 / \mathrm{L} 1$ & . & Stating & $\sqrt{ }$ & & & $\sqrt{ }$ & & & & & $\mathrm{H}$ is convinced \\
\hline & & & & & & & & & & & \\
\hline
\end{tabular}

Notes:

$\begin{array}{llll}\text { T1/P1/L1: Transcript 1/Paragraph 1/Line } 1 & \text { Asr } & : \text { Assertive } \\ \mathrm{H} & \text { : Hearer/Audience } & \text { Dir } & : \text { Directive } \\ \mathrm{D} & \text { : Declarative } & \text { Com } & : \text { Commissive } \\ \mathrm{In} & : \text { Interrogative } & \text { Exp } & : \text { Expressive } \\ \mathrm{Im} & : \text { Imperative } & \text { Dec } & : \text { Declarative }\end{array}$

After analyzing and getting the data to the data sheet, the formula proposed by Arikunto (1992) was applied for calculating the occurrence frequency of locutionary acts, illocutionary acts, and perlocutionary acts. $n \%=\frac{F}{N} \times 100$ In which: $n$

: the result

$\mathrm{F} \quad$ : the frequency of each type

$\mathrm{N} \quad$ : the total number of frequency

The procedures of data collection were pointed up using some steps: First, the downloaded videos of the speeches were watched and listened with awareness in order to transcribe and analyze the intonation and gesture of the speaker. Second, the transcripts were

\footnotetext{
${ }^{1}$ https://www.youtube.com/watch?v=0bUSAGrhCGw\&t=95s

${ }^{2}$ https://live.worldbank.org/plenary-annual-meetings-2018
} 
read carefully and coded them in order to classify the data based on the categorization. Third, the data were tabulated into the data sheet. Forth, the data were selected from the speeches which were in accordance with the objective of the study in order to support the depth analysis. The next procedure after data collection was data analysis.

The first statement of the problem which was meant to describe the types of speech acts was answered by these steps: First, the downloaded selected speeches were transcribed by watching and listening them cautiously. Second, the speeches transcripts were read carefully in order to do the note taking and sort them by looking for units of words, phrases, and sentences. The significant data were underlined and coded in order to ease the identification. Fourth, the selected data were tabulated into the data sheets which contain the speech acts classification proposed by Austin (1962) and Searle (2005). Fifth, the classified data were calculated the occurrence frequency of each types of speech acts in order to identify the dominant ones.

The second statement of the problem which was aimed to describe the reasons why Jokowi performed the kind of illocutionary acts viewed from the context of situations underlying the speeches was answered by intensely analyzing words, phrases, and sentences considering the concept of felicity condition and the context of situation based on Holmes' theory. The supporting data were taken from the articles of trustworthy newspapers, journals and official websites.

The third statement of the problem which was intended to describe the prospective perlocutionary effects of the dominant illocutionary found in Jokowi's speeches was answered by deeply analyzing the types of perlocutionary acts according to Austin's theory. The supporting data were in the form of some government policies (politic, economy, or socio-cultural) which were related to those selected speeches based on the political discourse concept. In addition, the effects of the speeches were also analyzed using the distinctive element of this study, namely cinematic reference. Again, the supporting data were taken from the articles of trustworthy newspapers, journals and official websites. The last, the data findings of the research were reported in order to draw the conclusion.

\section{FINDINGS AND DISCUSSION}

This finding and discussion consists of three parts. First, it describes the types of speech acts that Jokowi delivered in his selected speeches. Second, it describes Jokowi's reasons for committing illocutionary acts seen from the context of the situation behind the speeches. Third, it describes the prospective perlocutionary effects of the dominant illocutionary acts found in Jokowi's speeches.

\section{THE TYPES OF SPEECH ACTS FOUND IN JOKOWI'S SPEECHES TEXTS}

The result of the data sheet in Table 2 shows the detail frequency of the locutionary acts, illocutionary acts, and perlocutionary acts as displays on table below.

Table 2. The Frequency of Locutionary Acts Found in Jokowi's Speeches Texts

\begin{tabular}{|c|l|c|c|}
\hline No & Locutionary Acts & Frequency & Percentage \\
\hline 1 & Declarative & 60 & $86 \%$ \\
\hline 2 & Imperative & 2 & $3 \%$ \\
\hline 3 & Interrogative & 8 & $11 \%$ \\
\hline \multicolumn{2}{|c|}{ Total } & 70 & $100 \%$ \\
\hline
\end{tabular}


Table 2 shows that the dominant locutionary acts found in Jokowi's speeches texts is declarative as it has a total percentage $86 \%$ while $11 \%$ is interrogative and $3 \%$ is imperative. The result is in line with the basic character of a speech which should be informative and persuasive. The informative speech can help the audience to comprehend a subject better while the persuasive speech can convince the audience to accept the speaker's point of view. It is different from seminar or workshop where the keynote speaker uses many imperative sentences in order to make the audience mastered the certain topic or skill. It is also in contrast to dialogue of a play which contains many interrogative sentences to construct interactive conversation among the casts.

A declarative locutionary act is when the speaker conveys something. Jokowi on his selected speeches provided much enlightenment regarding the current global economic situation. He conveyed various information and ideas on how to overcome the economic global threats today. An interrogative locutionary act is when the speaker asks question. Jokowi on his selected speeches stated several questions to the audiences to get their attention. The interrogative sentences are actually rhetorical sentences which actually do not need to be answered. It is because mostly speech is a one-way communication. The questions are more about attracting the audiences whose are the policy makers to think for a moment on how to solve various global economic problems today. At the same time, Jokowi makes the audiences curious about his answers which portray his perspective. An imperative locutionary act is when the speaker gives order. There are only few sentences in Jokowi's selected speeches which indicate as imperative sentences. However, those are more like recommendation than orders. It is because the speech occasion is on international economic forum which support by a collective power.

Table 3. The Frequency of Illocutionary Acts Found in Jokowi's Speeches Texts

\begin{tabular}{|c|c|c|c|c|}
\hline No & Illocutionary Acts & Illocutionary Force & Frequency & Percentage \\
\hline \multirow{7}{*}{1} & \multirow{6}{*}{ Assertive } & a. Informing & 12 & $31 \%$ \\
\hline & & b. Asserting & 11 & $29 \%$ \\
\hline & & c. Affirming & 5 & $13 \%$ \\
\hline & & d. Predicting & 5 & $13 \%$ \\
\hline & & e. Assuring & 3 & $7 \%$ \\
\hline & & f. Questioning & 3 & $7 \%$ \\
\hline & \multicolumn{2}{|r|}{ Total } & 39 & $55 \%$ \\
\hline \multirow{4}{*}{2} & \multirow{3}{*}{ Directive } & a. Urging & 9 & $50 \%$ \\
\hline & & b. Requesting & 5 & $28 \%$ \\
\hline & & c. Recommending & 4 & $22 \%$ \\
\hline & \multicolumn{2}{|r|}{ Total } & 18 & $26 \%$ \\
\hline 3 & Commissive & a. Promising & 1 & $2 \%$ \\
\hline \multirow{7}{*}{4} & \multirow{6}{*}{ Expressive } & a. Greeting & 4 & $34 \%$ \\
\hline & & b. Thanking & 3 & $25 \%$ \\
\hline & & c. Praising & 2 & $17 \%$ \\
\hline & & d. Welcoming & 1 & $8 \%$ \\
\hline & & e. Congratulating & 1 & $8 \%$ \\
\hline & & f. Closing & 1 & $8 \%$ \\
\hline & \multicolumn{2}{|r|}{ Total } & 12 & $17 \%$ \\
\hline 5 & Declarative & -- & 0 & $0 \%$ \\
\hline \multicolumn{3}{|c|}{ Total General } & 70 & $100 \%$ \\
\hline
\end{tabular}

Table 3 above shows that the frequency of illocutionary acts found in Jokowi's speeches texts consists of assertive, directive, commissive, and expressive. Assertive has the 
highest frequency of occurrence 39 of 70 (55\%). It is followed by directive, expressive, and commissive which occurred respectively 18 of $70(26 \%), 12$ of $70(17 \%)$, and 1 of $70(2 \%)$. There is zero declarative illocutionary acts because both of the speech occasions are on the international economic forum which uphold collective decisions, not orders from one party. Moreover, it takes the special circumstance to perform a declarative illocutionary act. It is done by someone in a specific institutional role and context. By taking a declarative act, a president can change the world. For instance, a declaration of war on terrorism stated in 2001 by President of United States of America, George W. Bush.

Referring to the data on the table 4.3 above, the various types of illocutionary acts found in Jokowi's speeches texts which consist of assertive, directive, commissive, and expressive are elaborated as follows.

Assertive is the statement which can be verified as true or false. It leads the speaker to the truth of the proposition being expressed. Jokowi had used mainly assertive acts on his selected speeches which occur 39 of the total 70 illocutionary acts frequency. From the total assertive percentage $(55 \%)$, it consists of several illocutionary forces which mean the communicative plans or the design behind the speaker's statements, they are: $31 \%$ of informing, $29 \%$ of asserting, $13 \%$ of affirming, $13 \%$ of predicting, $7 \%$ of assuring, and $7 \%$ of questioning. Among those five of verbs associated with the assertive act, informing is the most dominant act.

Directive is the statement asking the hearer or the audience to do something. Jokowi had performed $26 \%$ of directive acts on his speeches which the frequency occurrence 18 of 70 excerpts of illocutionary acts. From the total percentage of directive act, it consists of several illocutionary forces which are $50 \%$ of urging, $28 \%$ of requesting, and $22 \%$ of recommending. Among those three verbs associated with the directive act, urging is the most dominant act.

Commissive is the statement which commit to a course of action. It binds the speaker to a specific future action. Promising is one of the various forms of this act. The data show that commissive act is the least used by Jokowi in his speeches which only occur once $(2 \%)$. He gave only one promise to the hearers or audiences. This fact is acceptable because Jokowi realized that the main mission of the leader's speech in international economic forum is not about transmitting political promises for his own interest. It is more about encouraging the audiences or the hearer to make a collective commitment for a brighter future. Jokowi committed as the leader of Indonesia, as one of many developing countries to stand ready preventing the most challenging global economic threats. He called this common enemy as "Thanos" who was defined as the misguided belief of the most countries that in order to succeed, others must surrender.

Expressive is the statement that expresses a psychological position about a state of affairs. The purpose of expressive acts is to express sincerity and sympathy of the speaker. This act is a part of manners in a formal speech. From the total expressive act percentage $(17 \%)$, it consists of several illocutionary forces which are: $34 \%$ of greeting, $25 \%$ of thanking, $17 \%$ of praising, $8 \%$ of welcoming, $8 \%$ of congratulating, and $8 \%$ of closing. 


\section{THE REASONS OF PRESENTING THE ILLOCUTIONARY ACTS VIEWED FROM THE CONTEXTS OF SITUATION}

The second objective of this research is to describe Jokowi's reasons for committing illocutionary acts seen from the context of the situation behind the speeches. It is answered by intensely interpreting words, phrases, and sentences considering the concept of felicity condition and the context of situation.

The first event in which Jokowi delivered his speech is World Economic Forum on ASEAN in Hanoi, Vietnam, September 12, 2018. The participants include not only about 900 political, business, academic and civil society leaders in the region, but also a group of 75 outstanding ASEAN start-ups. The state leaders who also act as the speakers are Nguyễn Xuân Phúc (Prime Minister of Vietnam), Samdech Techo Hun Sen (Prime Minister of Cambodia), Joko Widodo (President of Indonesia), Tun Dr Mahathir bin Mohamad (Prime Minister of Malaysia), Aung San Suu Kyi (State Counselor of Myanmar), Lee Hsien-Loong (Prime Minister of Singapore) and Rodrigo R. Duterte (President of Philippines).This forum was actually held on 11-13 September 2018 with the theme "ASEAN 4.0: Entrepreneurship and the Fourth Industrial Revolution". As a group, the 10 countries that make up ASEAN are the fifth largest economies in the world. It is a region that has undergone an extraordinary transformation in the half a century since its founding, and is now in the spotlight as global power shift to Asia. The forum agenda are focus on the innovations needed to drive the region through the next phase of growth. From tech unicorns to tensions in the South China Sea, the biggest opportunities and obstacles lie ahead. Furthermore, the forum ${ }^{3}$ also discussed strategic issues of national and regional interest under three thematic pillars: Entrepreneurship to build new approaches to regional and global governance; Entrepreneurship to strength economic and business dynamism; and Entrepreneurship to construct social inclusion.

The second event in which Jokowi conveyed his speech is the plenary session of the International Monetary Fund (IMF) and World Bank Annual Meetings in Nusa Dua Bali, Indonesia, October 12, 2018. Participants include central bank governors, ministers of finance and development, members of parliament, private sector executives, representatives from civil society organizations and academics. The Annual Meeting of the two financial institutions is the largest meeting in the fields of economy, finance and development at the global level that brought collectively government parties (Finance Ministers and Central Bank Governors) from 189 countries and non-government parties managing global finance and economy (https://klcfiles.kemenkeu.go.id).The Annual Meetings is held on 8-14 October 2018. Every three years, it is held in one of the member-countries that receives the most support from other countries through an open voting process. The main agenda of the meeting ${ }^{4}$ was to discuss issues of global concern, including the world economic projection, global financial strength, jobs and growth, economic development, aid effectiveness, poverty suppression and climate change.

As the host country for this prestigious event, Indonesia used this opportunity to show the world about its various potential resources. Even more, Bali could be the great showcase to impress the world about economics, craft and culture. They can have a quick view of Indonesia. The world has to know that Indonesia is the largest Muslim majority democracy and the world's fourth most populous nation which highly upholds tolerance for diversity. Also, Indonesia successfully hosted for world-class events in 2018. They are: (1) Asian

\footnotetext{
${ }^{3}$ www.weforum.org

${ }^{4}$ https://meetings.imf.org
} 
Games, Asia's largest sport event that was held in Jakarta and Palembang, in AugustSeptember 2018; (2) Asian Para Games, Asia's sport festival for persons with disabilities between 6 and 13 October 2018 in Jakarta; (3) The Annual Meetings of International Monetary Fund \& World Bank Group in Nusa Dua, Bali, on 8-14 October 2018, And (4) Our Ocean Conference, a meeting on maritime affairs that was attended by eight Heads of State on 29-30 October 2018, also in Bali. The four events went well and received appreciations from many parties. On the other hands, during the last few weeks before the meetings, the Indonesian people were hit by the earthquake and tsunami disaster on the island of Sulawesi. This context of situation could be a trigger to make collaboration among members country in managing aid effectiveness to speed up the recovery.

The most dominant illocutionary act found in Jokowi's speeches texts is assertive $(55 \%)$ which consists of informing (31\%), asserting (29\%), affirming (13\%), predicting $(13 \%)$, assuring $(7 \%)$, and questioning $(7 \%)$. Among those five of verbs associated with the assertive act, informing is the most dominant act. It is because he wants to attract the audiences by informing some current global economic trends and challenges to lead their framework to his point of view. Specifically, he wants to give background information why change has to be made since he realized that the world has change. Experiencing the national change may provide opportunities for other countries to take parts for mutual benefits. By doing this act, he can transmitted the agenda which he has formulated. The second highest assertive act performed by Jokowi in his speeches texts is asserting. The reasons of performing this act because he wants to let the audience feel the same awareness on the rising economic global threats which still shadow the most of developing countries. Affirming is the next assertive act performed by Jokowi in his speeches because he wants to verify the importance of global cooperation to compete in global economic expansion. Another assertive act which Jokowi performed in his speeches is predicting. The reason is because he wants to convince the audiences who are the prior policy makers among developing countries to immediately agree for a global economic cooperation. He made some horrific predictions in order to frighten the audience if they do not make it happen soon. Assuring is assertive act which also found in Jokowi's speeches. Based on the context, he performs this act because he wants to let the audience know about his beliefs which show his optimism of economic equality among nations through the fourth industrial revolution. Questioning is also belongs to assertive acts found in Jokowi's speeches texts. He performs this act because of two reasons: first, he wants to grasps the audience attention by making the attractive questions. Second, he wants to emphasize certain issues and confirm the participation by asking question to the audience.

The second type of illocutionary acts presented by Jokowi in his speeches texts is directive which occur $26 \%$. It consists of $50 \%$ of urging, $28 \%$ of requesting, and $22 \%$ of recommending. Urging is the directive act found most frequently in Jokowi's speeches texts. He performed this act because he wanted to encourage and insist the audiences to take concrete actions immediately to stand ready facing various challenges in the current global economy. Requesting is directive act which also found in Jokowi's speeches. The reason why he performed this act is to build trust among the nations that developing countries also have the potential strength to avoid the trade war. He wants to gather the global cooperation commitment. Recommending also belongs to the directive act which Jokowi performed in order to provide some recommendations to the global fiscal and monetary policy makers to join hands to overcome the global economic threats. The third type of illocutionary acts found in Jokowi's speeches texts is commissive which only occur once (2\%). It is because he understands that the act of promising is not the prior in the international forum. He committed 
as the leader of Indonesia, as one of many developing countries to stand ready preventing the most challenging global economic threats. it sounds like more about encouraging instead of promising the audiences or the hearer to make a collective commitment. The last type of illocutionary acts found in Jokowi's speeches texts is expressive which occur 17\%. It consists of several illocutionary forces which are: $34 \%$ of greeting, $25 \%$ of thanking, $17 \%$ of praising, $8 \%$ of welcoming, $8 \%$ of congratulating, and $8 \%$ of closing. These acts performed because he wants to create bonding and empathy to the audience. As a result, the message of the speeches may be conveyed smoothly and seep into the mind and soul of the audiences. Specifically when he stated his gratitude to the global economic leaders for the attention, support, and aid for the disaster which hit Indonesia few past weeks before the meeting

\section{THE PROSPECTIVE PERLOCUTIONARY EFFECTS OF THE DOMINANT ILLOCUTIONARY ACTS FOUND IN JOKOWI'S SPEECHES}

The third objective of this research is to describe the prospective perlocutionary effects of the dominant illocutionary found in Jokowi's speeches. These are answered by deeply analyzing the types of perlocutionary acts according to Austin's theory. The supporting data are in the form of some government policies (politic, economy, or socio-cultural) which were related to those selected speeches based on the political discourse concept. In addition, the effects of the speeches are also analyzed using the distinctive element of this study, namely cinematic reference. The characters, plots, and moral values of the cinematic references used in the speeches provided the scenarios which can be used to predict the prospective effects done by the hearer or the audience. First, Jokowi took the analogy of the "Avengers: Infinity War" movie to illustrate the threats facing the world today in his speech on the World Economic Forum on ASEAN in Hanoi, Vietnam, September 12, 2018. Second, he dropped another cinematic reference by making a comparison of the current global economic situation with the TV series "Game of Thrones" in his speech at the plenary session of the International Monetary Fund (IMF) and World Bank Annual Meetings in Nusa Dua Bali, Indonesia, October 12, 2018.

Table 4. The Frequency of Prospective Perlocutionary Acts Found in Jokowi’s Speeches Texts

\begin{tabular}{|c|l|c|c|}
\hline No & Prospective Perlocutionary Acts & Frequency & Percentage \\
\hline 1 & H is doing something & 19 & $27 \%$ \\
\hline 2 & H is impressed & 17 & $24 \%$ \\
\hline 3 & H is convinced & 12 & $17 \%$ \\
\hline 4 & H is attracted & 11 & $16 \%$ \\
\hline 5 & H feels irritated & 5 & $7 \%$ \\
\hline 6 & H feels frightened & 4 & $6 \%$ \\
\hline 7 & H is inspired & 2 & $3 \%$ \\
\hline \multicolumn{2}{|c|}{ Total } & 70 & $100 \%$ \\
\hline
\end{tabular}

Table 4 above shows the frequency of perlocutionary acts found in Jokowi's speeches texts. Hearer is doing something has the highest percentage which occur $27 \%$. It is followed by Hearer is impressed (24\%), Hearer is convinced (17\%), Hearer is attracted (11\%), Hearer feels irritated (7\%), Hearer feels frightened (6\%)and Hearer is inspired (3\%).

Referring to the research findings, the dominant illocutionary acts found in Jokowi's speeches texts are assertive (55\%) and directive (26\%). The assertive act consists of 
informing, asserting, affirming, assuring, questioning and predicting while the directive act consists of urging, requesting and recommending. The connection pattern between the illocutionary acts and the perlocutionary acts are drawn as described below.

The perlocutionary acts represent an outcome or by-product of speaking whether intentional or not. Among those assertive acts, informing and asserting has the highest frequency which occur $31 \%$ and $29 \%$. As a result, the prospective perlocutionary effects which occur are the hearers or the audiences are attracted and impressed by the information given then they are inspired to have or to do something. By knowing that information, the audiences are both attracted and impressed. They feel amaze of the potency of human resources which also developing countries had today. They are also enthusiast of the new economic trend which is industrial revolution 4.0. It provides the inspiration for other countries to boost policies related to human resource development program and technologybased creative economy. There is also an assertive act which makes the audiences feel irritated or frightened of the information given. But, this feeling is deliberately generated by the speaker so that the audiences take some precaution as intended. For instance, these excerpts give the information which intentionally could irritate or even frighten the hearer in order to lead the audiences to act in preventing the global financial crisis and trade war.

Affirming, assuring, questioning and predicting are the type of assertive acts which potentially convince the audiences about something as intended by the speaker. For example, when Jokowi convinced the audiences about the potential economic threats and the way to avoid them or when he predicts that even a winner countries will also suffering if there is no economic cooperation.

The following dominant illocutionary act which consists of urging, requesting and recommending is directive act. It has a possible perlocutionary effect which is the hearer is doing something. The audiences may perform some actions because of the ideas conveyed by the speaker is very provoking. They will immediately agree to the idea of creating a collective power and nurturing collaboration and partnership to breakdown many economic barriers

As an enrichment analysis, the effects of the speeches are also analyzed using the distinctive element of this study, namely cinematic reference. First, Jokowi took the analogy of the "Avengers: Infinity War" movie to illustrate the threats facing the world today in his speech on the World Economic Forum on ASEAN in Hanoi, Vietnam, September 12, 2018. In the beginning, Jokowi build the same perception about the definition of some terms used. "Thanos" used to personify the greed of each state to become superiors to others. The audiences may have initially mistaken for thinking Thanos is a developed country such as United States of America, China or Russia. "The infinity war" used to portray the current global economic situation in which limited natural resources are contested among nations such as petroleum, natural gas and coal. And "Avengers" are meant the countries that are committed forming collective power to gain economic equality among nations. Second, Jokowi dropped another cinematic reference by making a comparison of the current global economic situation with the TV series "Game of Thrones" in his speech at the plenary session of the International Monetary Fund (IMF) and World Bank Annual Meetings in Nusa Dua Bali, Indonesia, October 12, 2018. At first, Jokowi developed the same perception about the definitions of some terms used. "The Game of Thrones" used to illustrate the trade war among nations which caused emerging countries experiencing a big market pressure from developed countries. "Evil Winter" used to show the economic hardest time today because of the global financial crisis. "Great Houses" used to point up the developed countries which are enjoying the rapid growth among others. 


\section{CONCLUSION}

Based on the findings and discussions of the research, the following conclusions can be drawn. First, the three types of speech acts according to Austin's and Searle's theory found in Jokowi's speeches texts consist of locutionary acts, illocutionary acts and perlocutionary acts. The two selected speeches which are on the World Economic Forum on ASEAN in Hanoi, Vietnam, September 12, 2018 and at the plenary session of the International Monetary Fund (IMF) and World Bank Annual Meetings in Nusa Dua Bali, Indonesia, October 12, 2018, contained 70 excerpts.

Locutionary acts found in Jokowi's speeches texts is declarative as it has a total percentage $86 \%$ while $11 \%$ is interrogative and $3 \%$ is imperative. The result is in line with the basic character of a speech which should be informative and persuasive. A declarative locutionary act is when the speaker conveys something. An interrogative locutionary act is when the speaker asks question. An imperative locutionary act is when the speaker gives order. Illocutionary acts found in Jokowi's speeches texts consists of assertive, directive, commissive, and expressive. Assertive has the highest percentage which is $55 \%$. It is followed by directive, expressive, and commissive which occurred respectively $26 \%, 17 \%$, and $2 \%$. There is zero declarative illocutionary acts because both of the speech occasions are on the international economic forum which uphold collective decisions, not orders from one party. The assertive acts consist of several illocutionary forces, they are: $31 \%$ of informing, $29 \%$ of asserting, $13 \%$ of affirming, $13 \%$ of predicting, $7 \%$ of assuring, and $7 \%$ of questioning. The directive acts consist of several illocutionary forces which are $50 \%$ of urging, $28 \%$ of requesting, and $22 \%$ of recommending. The commissive act is the least used by Jokowi in his speeches which only occur $2 \%$ of promising. The last is expressive act which consists of $34 \%$ of greeting, $25 \%$ of thanking, $17 \%$ of praising, $8 \%$ of welcoming, $8 \%$ of congratulating, and $8 \%$ of closing.

Jokowi presented the illocutionary acts due to various reasons viewed from the context and felicity condition according to Holmes' theory. The reasons of presenting assertive acts include giving background information why change has to be made since he realized that the world has change, allowing the audiences to feel the same awareness on the rising economic global threats which still shadow the most of developing countries, convincing the audiences who are the prior policy makers among developing countries to immediately agree for a global economic cooperation, and showing his optimism of economic equality among nations through the fourth industrial revolution. The reasons of presenting directive acts include encouraging the audiences to take concrete actions immediately to stand ready facing various challenges in the current global economy, building trust among the nations that developing countries also have the potential strength to avoid the trade war, providing some recommendations to the global fiscal and monetary policy makers to join hands to overcome the global economic threats. The reasons of presenting commissive acts include encouraging instead of promising the audiences or the hearer to make a collective commitment for a brighter future. The last, the reasons of presenting expressive acts include creating bonding and empathy to the audience. As a result, the message of the speeches may be conveyed smoothly and seep into the mind and soul of the audiences.

The prospective perlocutionary effects of the dominant illocutionary found in Jokowi's speeches are answered by deeply analyzing the types of perlocutionary acts according to Austin's theory. The frequency of perlocutionary acts found in Jokowi's speeches texts. Hearer is doing something has the highest percentage which occur $27 \%$. It is followed by Hearer is impressed (24\%), Hearer is convinced (17\%), Hearer is attracted 
(11\%), Hearer feels irritated (7\%), Hearer feels frightened (6\%)and Hearer is inspired (3\%). Referring to the research findings, the dominant illocutionary acts found in Jokowi's speeches texts are assertive (55\%) and directive (26\%). The prospective perlocutionary effects of the assertive acts include the audiences feel amaze of the potency of human resources which also developing countries had today. They are also enthusiast of the new economic trend which is industrial revolution 4.0. It provides the inspiration for other countries to boost policies related to human resource development program and technology-based creative economy. As well the audiences are convinced about the potential economic threats and the way to avoid them by economic cooperation. The prospective perlocutionary effects of the directive acts include the audiences immediately agree to the idea of building a collective power and nurturing collaboration and partnership to breakdown many economic barriers.

Finally, the use of these famous cinematic references which are "Avengers: Infinity War" and "Game of Thrones" may double the effects to the hearer's actions because of several reasons. First, the audience is more interested in familiar and entertaining things, especially in serious formal forum. It is such a refreshing anomaly. Second, the audience simply understands the messages conveyed by using setting, plot, and character of the movie as analogy. The use of evil characters from the movie and series as an analogy to global threats and challenges creates the "Common Enemy" that the audiences as policy makers must fight together. The last, the feeling of participating in a situation depicted just like when watching a movie can encourage the audiences' action to do something as intended.

\section{REFERENCES}

Arikunto, S. (1992). Prosedur Penelitian: Suatu Pendekatan Praktik. Jakarta: PT Rineka Cipta.

Arsajad.(2019). Definisi Pidato.Retrieved May 20, 2020, from https://seputarilmu.com /2019/02/macam-macam-pidato.html.

Austin, J. L. (1962). How to Do Things with Words. New York: Oxford University Press.

Cruse, A. (2006). A Glossary of Semantics and Pragmatics. Edinburg: Edinburg University Press Ltd.

Finch, G. (2000). Linguistic: Terms and Concepts. New York: Palgrave.

Gorbiano, M. I. (2018). Winter is Coming, Jokowi Tells Fiscal, Monetary Policymakers. Retrieved May 20, 2020 from The Jakarta Post October 12, 2018 Website: https:/www.thejakartapost.com/news/2018/10/12/winter-is-coming-jokowi-tellsfiscal-monetary-policymakers.html.

Holmes, D. (2015). Communication Theory: Media, Technology, and Society. London: Sage Publication

Leech, G. (1983). Principles of Pragmatics. New York: Longman.

Rahardi, K. (2005). Pragmatik: Kesatuan Imperatif Bahasa Indonesia. Jakarta: Penerbit Erlangga.

Rita Mae Brown Quotes. (n.d.). BrainyQuote.com. Retrieved November 15, 2020, from BrainyQuote.com Website: https://www.brainyquote.com/quotes/rita mae_brown_382533.

Searle, J. R. (2005). Expression and Meaning: Studies in the Theory of Speech Acts. Cambridge: Cambridge University Press.

Septiari, D. (2018). Trade War Must Not Become 'Infinity War': Jokowi.Retrieved May 20, 2020, from The Jakarta Post. September 13, 2018 Website: 
New Language Dimensions

Volume 2(1) 2021

ISSN: 2746-8968 (online)

https://journal.unesa.ac.id/index.php/nld/index

https://www.thejakartapost.com/news/2018/09/13/trade-wars-avengers-infi nity-warthanos-jokowi-world-economic-forum.html. 